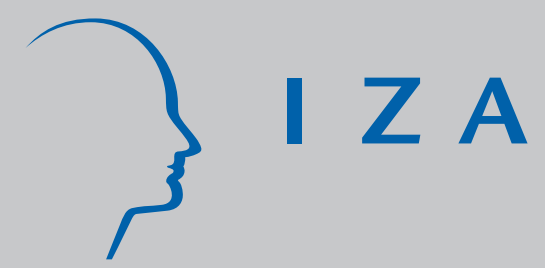

IZA DP No. 7848

Couples' Time Together: Complementarities in Production versus Complementarities in Consumption

Hani Mansour

Terra McKinnish

December 2013 


\title{
Couples' Time Together: Complementarities in Production versus Complementarities in Consumption
}

\author{
Hani Mansour \\ University of Colorado Denver \\ and IZA \\ Terra McKinnish \\ University of Colorado Boulder
}

\section{Discussion Paper No. 7848 \\ December 2013}

\author{
IZA \\ P.O. Box 7240 \\ 53072 Bonn \\ Germany \\ Phone: +49-228-3894-0 \\ Fax: +49-228-3894-180 \\ E-mail: iza@iza.org
}

\begin{abstract}
Any opinions expressed here are those of the author(s) and not those of IZA. Research published in this series may include views on policy, but the institute itself takes no institutional policy positions. The IZA research network is committed to the IZA Guiding Principles of Research Integrity.

The Institute for the Study of Labor (IZA) in Bonn is a local and virtual international research center and a place of communication between science, politics and business. IZA is an independent nonprofit organization supported by Deutsche Post Foundation. The center is associated with the University of Bonn and offers a stimulating research environment through its international network, workshops and conferences, data service, project support, research visits and doctoral program. IZA engages in (i) original and internationally competitive research in all fields of labor economics, (ii) development of policy concepts, and (iii) dissemination of research results and concepts to the interested public.
\end{abstract}

IZA Discussion Papers often represent preliminary work and are circulated to encourage discussion. Citation of such a paper should account for its provisional character. A revised version may be available directly from the author. 
IZA Discussion Paper No. 7848

December 2013

\title{
ABSTRACT \\ Couples' Time Together: Complementarities in Production versus Complementarities in Consumption
}

\begin{abstract}
Economists have previously suggested that gains from marriage can be generated by complementarities in production (gains from specialization and exchange) or by complementarities in consumption (gains from joint consumption of household public goods and joint time consumption). This paper uses the American Time Use Survey (ATUS) from 2003-2011 to test whether couples that engage in less specialization (are more similar in hours of market work) spend more time together. We find that among married couples without young children, those with a greater difference in weekly hours of work between husband and wife spend less time together on non-working weekend days. Importantly, we find that this relationship is quite symmetric between couples in which the husband works greater hours and couples in which the wife works greater hours. We do not find evidence of a relationship between specialization and couple time together among couples with young children.
\end{abstract}

JEL Classification: J12, J13, J16

Keywords: $\quad$ time use, home production, joint consumption

Corresponding author:

Hani Mansour

Department of Economics

University of Colorado Denver

Campus Box 181

P.O. Box 173364

Denver, CO 80217-3364

USA

E-mail: hani.mansour@ucdenver.edu 


\section{Introduction}

Economists have noted that technological changes and rising wages of women have reduced household specialization and gains from marriage based on complementarities in production. As a result, household specialization does not appear to be sufficient in many couples to be the primary source of marital surplus. Previous researchers have proposed that joint consumption of household public goods and leisure are another source of marital surplus (Lam, 1988; Stevenson and Wolfers, 2007; Lundberg, 2012). Therefore, we might think of the stock of married couples as a mix of those who generate their marital surplus largely through complementarities in production and those who generate their marital surplus largely through complementarities in consumption.

To the extent that complementarities in consumption are an important source of marital surplus, one potential measure of interest is the joint time consumption of married couples. For instance, Fisher et al. (2007) analyze time diary data spanning more than 40 years and show that over time married couples have increased the time spent together in various activities. Using data from the American Time Use Survey (ATUS) 2003-2011, this paper specifically tests whether couples that engage in less specialization (are more similar in hours of market work) spend more time together, which would be consistent with a model in which they generate more gains from joint consumption.

This paper specifically focuses on joint time consumed with spouse on non-working weekend days. Much of the existing literature on couple time use has focused on couple's synchronization of work hours on workdays, and time use allocations between market work, household production and leisure on a given day. Relatively little work has focused on the amount of time couples actually spend together, and what little there is has also tended to focus 
on workdays. In contrast, we specifically study days on which married individuals report no market work. This approach, we argue, allows us to analyze behavior more fundamentally related to preferences, rather than outcomes that reflect constraints imposed by different flexibility in work hours for people with different labor market characteristics.

Our primary analysis focuses on dual-earner couples. Among married dual-earner couples, we find that couples with a greater difference in weekly hours of work between husband and wife spend less time together on non-working weekend days. Specifically, a couple in which one spouse works 20 hours a week more the other is predicted to spend 27.2 fewer minutes together on a non-working weekend day compared to spouses with equal work hours. This is about $56 \%$ of the effect of having a child on couple time together. When the analysis is stratified by the age of youngest child, we find no evidence of this relationship for couples whose youngest child is 12 or under, but that the relationship between specialization and joint time consumption does exist for couples with older children and for couples with no children living at home.

Importantly, we find that the relationship between specialization and couple time together is quite symmetric between couples in which the husband works greater hours and couples in which the wife works greater hours. Greater specialization is associated both with less joint time in household production and less joint time in leisure. The magnitude of the relationship is weaker when non-working spouses are included in the sample.

The remainder of the paper is organized as follows: Section II reviews the literature and discusses the predicted relationship between specialization and couples’ time together; Section III describes the ATUS data and our sample; Section IV describes the empirical specifications and Section V discusses the results. 


\section{Marital Surplus and Couples’ Time Together.}

In a model of marriage in which marital surplus is generated by production complementarities and gains from specialization, there are larger gains to marriage when individuals with high relative returns to market work marry spouses with low relative returns to market work, in other words, negative assortative matching on market wages (Becker, 1981). An alternative source of marital surplus is complementarities in consumption, which can result from risk pooling, joint consumption of household public goods (such as children) and the direct utility of time spent together. In the latter case, larger gains to marriage are generated when individuals match with spouses with similar preferences for consumption (Lam, 1988; Lundberg, 2012).

Couples who generate marital surplus through specialization and exchange do not necessarily need to like each other or enjoy spending time together in order for the utility in the married state to dominate utility in the unmarried state. ${ }^{1}$ In contrast, couples that engage in relatively little specialization likely require compatibility of preferences and positive utility from joint consumption in order to generate sufficient marital surplus. Lundberg (2012) analyzes the effect of personality traits on selection into marriage using the German Socio-economic Panel Study. She finds that among older cohorts, personality traits affect selection into marriage very differently for women and men, consistent with gender specialization in marriage. For example, agreeableness increases marriage for women, but decreases it for men. This is consistent with selection into marriage of women who are nurturing and men with earnings

\footnotetext{
${ }^{1}$ It should be noted, however, that while couples that specialize do not need to enjoy each other's company, they do need to trust each other's commitment to the marriage. For example, a wife who doubts whether her marriage will last will be much more reluctant to specialize in household production, lowering her potential earnings in the event of divorce. To the extent that couples that are less certain of their marital stability will specialize less, this will bias us away from finding that less-specialized couples spend more time together.
} 
power. In contrast, for younger cohorts, she finds no difference between men and women in how personality predicts marriage. This is consistent with marital surplus generated from joint consumption, rather than specialization.

In this paper, we test whether couples that are less specialized, as measured by differences in weekly hours of work, do in fact spend more time together. While surprisingly little research has used differences in hours of market work as a dependent or independent variable, Lundberg and Rose (1999) study changes in specialization, as measured by the differences in hours of work, following the birth of a child using the Panel Study of Income Dynamics. They find that specialization increases with the birth of the first child, but less so for couples who eventually divorce.

\section{A. Prior research on married couple time use}

In the literature on couples' time use, much of the previous work on couples' joint time use has focused on the synchronization of work activities, meaning whether couples adjust the timing of the work activities to increase the amount of time they are simultaneously away from work. Sullivan (1996), Hamermesh (2002), and Jenkins and Osberg (2005) find evidence that couples prefer to synchronize their work activities. Using data from the May CPS Supplements, Hamermesh (2002) found that in the 1970s the degree of work time synchronization was increased much more by an increase in the wife's wage than the husband's, but in the 1990 the effects were essentially equivalent. He also found that increases in the husband's or wife's hours of work produce equivalent reductions in the degree of synchronization. Hamermesh was only able to determine whether or not couples were at work at the same time. He could not determine whether or not the couples were spending their time together when they were not at work. 
Hallberg (2003) specifically analyzes the amount of time couples spend together conditional on synchronization of activities. Using data from Sweden, he first calculates the total time that couples spend in synchronized non-work activities (i.e. they are both engaged in leisure at the same time or both engaged in household production at the same time, but not necessarily with each other). ${ }^{2}$ He then calculates the fraction of synchronized time that the couple actually spends together. He analyzes how both synchronized time and the fraction of synchronized time that is joint time vary by husband's and wife's income and hourly wage rate using a sample of dual-earner couples reporting weekday time use. He theorizes that high income couples are able to spend more time together since they can afford to buy some services that otherwise they would have to do on their own (e.g. child care or house chores), but that high income couples also may have more activities than low income couples, increasing the trade-off cost between these activities and the time spent together with the spouse. Controlling for hours of market work on the same day, Hallberg (2003) finds no effect of either spouse’s wages or income on hours of synchronized time. Conditional on synchronized time, but not hours of market work, the fraction that is jointly consumed increases with both husband's and wife's income.

In another study of couple time together, Morrill and Pabilonia (2012) estimate the effect of state unemployment rates on couple joint time. They find a U-shaped relationship in which increases in the unemployment rate initially decrease couple time together, but then the relationship reverses. They argue that initial declines in economic conditions may be felt

\footnotetext{
${ }^{2}$ Because the observed timing of work can be an artifact of how a society is organized, Hallberg (2003) tested the leisure synchronization hypothesis by constructing artificial households of single men and women for whom only societal factors should impact their time synchronization. The results indicate that the hours couples spend in the market is significantly interdependent, even after differencing out synchronization behavior that stems out from the way a society is organized.
} 
through changes in work schedules (shifts to evening and weekend work) that reduce couple time together, but at higher levels of unemployment job loss may increase couple time together. ${ }^{3}$ Using ATUS data, Connelly and Kimmel (2009) do not study couple time together, but they do study how one spouse's time use choices affect the choices of the other spouse. They analyze individual's time use in leisure, child care and non-child care household production as a function of the relative wage with spouse, spouse's weekly hours and spouse's time use on the same three non-market activities. They find little evidence that spouse's labor market characteristics or time use affects own time use, other than a positive complementarity for leisure.

\section{B. Predictions for specialization and joint time use}

This paper estimates the difference in joint time use across couples with different levels of specialization (in weekly hours of work). This approach assumes that joint time use is a useful proxy for a couple's gains from joint consumption. While it is unlikely that joint time with spouse is perfectly correlated with gains from joint consumption, it seems very reasonable that the correlation is positive. We argue that it is unlikely that couples that generate larger gains from joint consumption actually spend less time together than couples with smaller gains from joint consumption.

Starting with the simple case in which there are only two sources of marital surplus (gains from specialization and gains from joint consumption) and all couples have the same marital surplus, we can think of all couples as located on the same downward-sloping indifference curve, but generating their utility through different combinations of specialization and joint consumption. Given our assumption that joint time use measures gains from joint

\footnotetext{
${ }^{3}$ Aguiar et al (2012) find that the decline in market work from macroeconomic shocks results in much larger substitution into leisure than household production, but that among married couples with children there is substantial substitution into childcare.
} 
consumption, this would generate a negative relationship between joint time together and specialization.

It is important to note that the most likely violations of the simple conceptual model above would bias us against finding a negative relationship between specialization and joint time. If, for example, there is another source of marital surplus (e.g. insurance/risk pooling) that is the primary source of marital surplus for couples with less specialization, then it could be the case that couples who do and do not specialize are similar in joint consumption and joint time together. In this case, we should not observe a negative relationship between specialization and joint time.

If it is the case that couples with greater specialization on average have greater marital surplus than couples who do not specialize (so that specialized couples are on a higher indifference curve than couples who do not specialize), then it could be the case that specialized couples enjoy as much joint consumption and joint time as non-specialized couples. Once again, we should not observe a negative relationship between specialization and joint time.

If, however, non-specialized couples have greater average marital surplus than specialized couples, this could cause us to overstate the negative relationship between specialization and joint time. We consider it unlikely that specialized couples on average generate less marital surplus than non-specialized couples.

\section{Data}

The data we use are drawn from the 2003-2011 waves of the American Time Use Survey (ATUS). Households in the ATUS are drawn randomly from the existing sample of the Current Population Survey (CPS). The ATUS is typically conducted 2-3 months after the final CPS survey and the respondent is randomly chosen from the list of adult household members (age 15 
or older). At the time of the survey, each respondent is asked to provide a 24-hour diary of his or her activities in the previous day. Respondents describe their activities to the interviewers who then code them using three-digit codes. In addition to collecting information on the duration of each activity, respondents are asked to report where they were during the particular activity and with whom. ${ }^{4}$ The U.S. Bureau of Labor Statistics aggregates the three-digit activity codes into 17 top-level categories, such as household activities, education, and socializing, relaxing and leisure. Each of the 2004-2011 ATUS sampled about 13,000 respondents while the 2003 survey includes a little over 20,000 respondents. More detailed information on the collection of the ATUS sample and on the different coding procedures can be found in Hamermesh, Franzis, and Stewart (2005).

While the ATUS provides very detailed activity codes, we categorized all activities as market work, household production, leisure or personal care. For each activity an individual records in their time diary, we know whether the activity was conducted with their spouse. The exception is personal care activities (sleeping, grooming, etc), for which respondents are not asked who was with them during the activity. Because we do not have any information about how much of their personal care time was spent jointly with spouse, we ignore this category of time use when calculating couples' time together, focusing only on joint time in leisure and in household production.

We match the time use data to information from the CPS on the weekly hours of work and weekly earnings for the ATUS respondents and their spouses, as well as information on the number and ages of children in the household.

The full analysis sample contains individuals who are a) married, b) both husband and wife are ages 20-55, c) filled out the time diary on a weekend and d) did not perform any market

\footnotetext{
${ }^{4}$ The specific question asked is "who was with you?/who accompanied you?"
} 
work on their diary day. ${ }^{5}$ Ideally, we would like a sample of days on which neither spouse works, but unfortunately, only one member of the household fills out a time diary, so we do not know whether the spouse works on the time diary day. For that reason, we limit our sample to weekend days, as we expect that it is much less likely that the spouse worked if it is a weekend day. Of ATUS respondents who meet sample selection criteria (a)-(c) above, 63.8 percent of men and 75.7 percent of women report no market work on their weekend time diary day, indicating that men are somewhat more likely to work on weekends. Therefore, the married women who fill out the time diary and qualify for our analysis sample are more likely to have a husband who works on the time diary day than the married men who fill out the time diary and qualify for our analysis sample.

Figure 1 is a histogram of total time with spouse (in minutes) on non-working weekend day for the full sample. Less than $7 \%$ of the sample reports no time with spouse on their day off. In our analysis, we first focus on the subset of couples in our full sample who are dual-earner couples, defined as couples in which both the husband and wife report positive weekly hours of work. Figure 2 replicates the Fig 1 histogram using just the dual-earner sample. The distribution of time with spouse is very similar to that observed in Figure 1.

Table 1 reports sample means for the full sample as well as the dual-earner sample in which both spouses report non-zero weekly hours of work. On average, respondents report a considerable 468 minutes of time with spouse on their non-working weekend day off, 138 spent together in household production and 330 minutes spent together in leisure. Because the average respondent spends 326 total minutes on household production and 453 total minutes on leisure, this indicates that married individuals specialize more with regards to household production and

\footnotetext{
${ }^{5}$ For the purposes of determining the analysis sample, education related activities are categorized as market work. An additional minor sample restriction to eliminate potential outliers is the exclusion of individuals who do not report at least 300 minutes of non-personal time on their time diary day.
} 
engage in joint consumption for a higher fraction of their leisure time. The dual-earner sample, as expected, has higher work hours, higher combined weekly earnings, higher education and fewer children on average, but very similar mean time with spouse.

\section{Methods}

The primary regression specification is:

$$
\begin{aligned}
\text { SpouseTime }_{i j t} & =\beta_{0}+\beta_{1} \mid \text { HusbHours }_{i}-\text { WifeHours }_{j}\left|+\beta_{2}\right| \text { HusbWage }_{i}-\text { WifeWage }_{j} \mid \\
& +\beta_{4} \text { WifeHours }_{j}+\beta_{5} \text { WifeWage }_{j}+\beta_{3} \log \left(\text { HusbWeeklyEarn }_{i}+\text { WifeWeeklyEarn }_{j}\right) \\
& +X_{i j} \beta_{7}+\text { Year }_{t}+\varepsilon_{i j t}
\end{aligned}
$$

where SpouseTime is total minutes spent by husband $i$ with wife $j$ on non-working weekend day in year $t$. HusbHours is the husband's weekly hours of work and WifeHours is wife's weekly hours of work. HusbWage and WifeWage are calculated hourly wages, and HusbWeeklyEarn and WifeWeeklyEarn are weekly earnings of the husband and wife. $X$ contains controls for female (whether it is the husband's or wife’s time diary report), husband's and wife's education (indicators for high school degree, college degree and advanced degree), age and age-squared, indicators for number of children (up to 4 or more), indicators for age of youngest child (six 3year age categories), husband's and wife's race and ethnicity (indicators for non-Hispanic black, non-Hispanic Asian, non-Hispanic other, and Hispanic) and indicator for Sunday (vs Saturday). Year is a vector of year indicators for survey years 2003-2011. All regressions are weighted using the ATUS personal sampling weights.

Following Lundberg and Rose (1999), we use the difference in husband's and wife's hours of market work as our measure of specialization. Figure 3 is a histogram of our key independent variable for the dual-earner sample, the absolute value of the differences in husband's hours and wife's hours. Not surprisingly, there is a big spike at 0 for couples who work the same hours, mostly couples in which both spouses work 40 hours per week. The 
remaining sample is spread out between 0 and 80 hours, providing substantial variation for estimating the relationship.

Equation (1) estimates the effect of the absolute value of the difference in hours between husband and wife controlling for wife's hours. One concern is that the raw difference in hours between husband and wife is largely positive, and that the more appropriate interpretation of $\beta_{1}$ is the effect of higher husband's hours of work rather than an effect of being a more specialized couple. Figure 4 is a histogram of the raw difference between husband's hours and wife's hours for the dual-earner sample. It shows that while husband's hours exceed wife's hours for the sizeable majority of couples, there does appear to be sufficient mass below zero to estimate the effect separately for the case in which wife's hours exceeds husband's hours.

Therefore, in equation (2) we interact the absolute value of the difference in husband's and wife's hours with indicator variables for whether the husband's hours exceeds the wife's or the wife's exceeds the husband's. This allows us to estimate separate effects depending on whether it is the husband or wife who is more specialized in market work.

$$
\begin{array}{r}
\text { SpouseTime }_{i j t}=\beta_{0}+\beta_{1} \mid \text { HusbHours }_{i}-\text { WifeHours }_{j} \mid * I\left(\text { HusbHours }_{i}>\text { WifeHours }_{j}\right) \\
+\beta_{2} \mid \text { HusbHours }_{i}-\text { WifeHours }_{j} \mid * I\left(\text { HusbHours }_{i}<=\text { WifeHours }_{j}\right) \\
+\beta_{3} \mid \text { HusbWage }_{i}-\text { WifeWage }_{j} \mid+\beta_{4} \text { WifeHours }_{j}+\beta_{5} \text { WifeWage }_{j} \\
+\beta_{3} \log \left(\text { HusbWeeklyEarn }_{i}+\text { WifeWeeklyEarn }_{j}\right)+X_{i j} \beta_{6}+\text { Year }_{t}+\varepsilon_{i j t}
\end{array}
$$

\section{Results}

\section{A. Dual-earner couples}

Column 1 of Table 2 reports the results from estimating equation (1) on the dual-earner sample. The coefficient on difference in husband's and wife's hours of work is -1.36 and is statistically significance. This indicates that a couple in which one spouse works 20 hours a week more than the other is predicted to spend 27.2 fewer minutes together on a non-working 
weekend day compared to spouses with equal work hours. Comparing the magnitude of this effect to the coefficient on the single child indicator reported in the same column, this is about $56 \%$ of the effect of having a child on couple time together. These results are consistent with a model in which couples that engage in greater specialization spend less time together.

What is additionally striking about the results in columns (1) is how few of the other variables in the model have a statistically significant effect on time spent with spouse. Couples in which the wife works more hours do spend less time together. The coefficient on female is large and highly significant. This is due to the fact, as discussed earlier, that men are more likely to work on the weekend than women. Therefore, the married women who fill out the time diary and qualify for our analysis sample are more likely to have a husband who works on the time diary day than the married men who fill out the time diary and qualify for our analysis sample.

Having children reduces the time couples spend together, with couples with one child spending about 49 fewer minutes together than those with no children. Interestingly, while there is a big difference between couples who have children and those who do not, the effect of additional children is much smaller. While additional children further decrease the amount of time the couple spends together, the coefficients on the indicators for number of children are not statistically different from each other. Additionally, conditional on number of children, the effect of age of youngest child is statistically insignificant except for youngest child ages 6-8.

Other variables that we might think important: the wage difference between husband and wife, couple's weekly earnings, the wife's wage, husband's and wife's age and education, are largely insignificant. A doubling of husband's and wife's weekly earnings is associated with a mere 1 minute increase in time spent together. While other research suggests that couple time together on work days is higher for higher earning couples, in part due to their greater ability to 
coordinate work schedules, the same does not appear to be the case for couples on non-working weekend days.

One concern with the ATUS data is that we only receive one spouse's report of time use, and therefore joint time with spouse. If we could observe both spouses' reports, the two reports of joint time with spouse could differ. If there is classical measurement error in our dependent variable, this does not generate any bias in our estimates. Previous research has shown that husbands and wives provide differing reports of husband's time in household production, but not differing reports of wife's time (Kamo, 2000; Lee and Waite, 2005). It is possible that men and women systematically differ in their reports of joint time with spouse. To check whether this affects our estimates, in column 2 of Table 2 we interact the hours differential with indicators for whether the time diary report is from the male or female spouse. The two coefficients are fairly similar in magnitude and are not statistically different. Our findings are very similar regardless of whether the time diary was reported by the husband or by the wife.

Columns 3 and 4 report versions of the specification in column 2 in which joint time with spouse is separated into joint time in household production and joint time in leisure. For both categories of time use, joint time is lower for couples with less specialization, though the effects on joint leisure are somewhat larger. There are some differential effects between joint time in household production and leisure for some of the control variables. A larger wage differential between husband and wife does lower joint time in household production, but not in leisure. Higher weekly hours of work for the wife reduce joint time in leisure, but not in household production. There is some evidence that wife's education increases joint leisure time. Finally, while age of youngest child has little affect on total joint time together, younger children do shift the composition of joint time use from leisure to household production. 
Table 3 reports estimates from equation (2) in which we differentiate between couples in which the husband is more specialized in market work and those in which the wife is more specialized in market work. The effects of the difference in work hours are quite symmetric between the two types of couples. When joint time is split into household production and leisure in columns (2) and (3), the two coefficients are essentially identical for household production. For leisure time, the hours differential for couples in which the wife works more hours appears to have a larger effect than the differential for couples in which the husband works more hours, but the difference between the two coefficients is not statistically significant.

Table 4 estimates equation (1) separately for couples whose youngest child is a pre-teen, those whose youngest child is a teenager, and those who do not have children under 18 at home. ${ }^{6}$ The results in column (1) suggest that there is no relationship between couple specialization and couple time together for couples with pre-teen children. In column (2), the coefficient on the hours differential for couples whose youngest child is a teenager is statistically significant and similar in magnitude to the estimates in Table 2. In columns (3) and (4), we report estimates for couples without children under 18 living at home, dividing the sample into two separate groups. Column 3 uses only those couples without children in which the wife is 36 years old or younger. This sample should disproportionately contain couples that have not yet had children. In column 4, the sample is couples without children at home in which the wife is age 37 or older. This sample should disproportionately contain couples who have had children, but no longer have children under 18 years old. For both samples, the coefficient on the hours differential is negative, statistically significant and larger in magnitude than estimates for couples with children under 18. The coefficient of -4.82 for couples without children and a wife age 36 or younger

\footnotetext{
${ }^{6}$ Because we are already splitting the sample into considerably smaller subsamples, it is problematic to further estimate a separate coefficient for couples in which the wife works greater hours.
} 
indicates that a couple in which one spouse works 20 hours a week more than the other is predicted to spend 96.4 fewer minutes together than spouses with equal work hours. The coefficient of -2.53 for couples without children and a wife age 37 or older indicates that a couple in which one spouse works 20 hours a week more than the other is predicted to spend 50.6 fewer minutes together than spouses with equal work hours. One possible interpretation of the results in Table 4 is that for couples with younger children, time with spouse is constrained in ways that reduce the influence of other factors.

These results in columns 3 and 4 of Table 4 are informative for another reason. One weakness of our data is that our sample is a select cross-section of surviving couples and we do not know how long a couple has been married. We can reasonably assume, however, that column 3 disproportionately contains recently married couples that have not yet had children and that column 4 disproportionately contains couples that have a much longer duration of marriage compared to those in column 3. The fact that we find a sizeable negative coefficient on the hours differential in both samples provides some evidence that our results would be robust to a control for duration of marriage. ${ }^{7}$

\section{B. Full Sample}

Table 5 reports estimates from equation (2) for the full sample. Because non-working spouses are now included in the sample, wife's wage and the wage differential are no longer included in the model. An indicator for whether the wife does not work is added in addition to the linear control for wife's hours. This allows for the possibility that joint time use for couples with a stay-at-home wife may differ from that of couples with a working wife in ways not fully captured by a linear control for working hours. In column 1, the estimates on the hours

\footnotetext{
${ }^{7}$ One possibility is to use age of oldest child as a proxy for duration of marriage. We only, however, observe age of children for those living at home, so this approach is only feasible for families with children at home. The estimates in columns 1 and 2 of Table 4 are robust to controls for age of oldest child at home and its square.
} 
differential for total time with spouse are negative, statistically significant, and symmetric between couples in which the wife works more hours and couples in which the husband works more hours. The magnitude is about half that estimated using the dual-earner sample.

Columns 2 and 3 of Table 5 split time with spouse into household production and leisure. As was the case in table 2, the hours differential estimates are negative for both categories of time use, but larger in magnitude for leisure.

Table 6 replicates the analysis by age of youngest child from Table 4 for the full sample. The primary difference between the results in Table 6 and those using the dual-earner sample in Table 4 is the smaller effect for couples whose youngest child is a teenager. It should be noted that the loss of statistical significance for couples with a teenage youngest child compared to the full sample results more from the loss of sample size and increase in standard error than the reduced magnitude of the coefficient. The estimate for couples with a teenage youngest child is roughly two-thirds that for the full sample.

\section{Conclusions}

The source of marital surplus is important as it generates predictions regarding how individuals will sort and match in the marriage market, and what sort of shocks will reduce the surplus and destabilize the marriage. This paper makes a modest step in understanding the source of marital surplus by confirming that couples who are less specialized in hours of work spend more joint time together. This is consistent with a model in which some couples generate marital surplus through gains from joint consumption rather than gains from specialization and trade.

We do not find any evidence of a negative relationship between specialization and joint time consumption for married couples with children ages 12 and under. It is not clear why this 
would be the case. Perhaps having young children places greater constraints on couple time together. It should be noted that joint consumption of a public good (such as children) also generates marital surplus, so it could be that couples with young children who specialize less on average make greater investments in their children and derive their marital surplus from joint consumption of this public good.

It is also important to recognize that our analysis is conducted on a cross-section of surviving marriages. Our analysis can only be interpreted as a comparison across couples that are currently married, in which case the sample is positively selected on marital surplus, with marriages with smaller surplus having disproportionately dissolved. While there is evidence that less specialized couples are more likely to divorce (Lundberg and Rose, 1999), our data do not allow us to consider whether joint time consumption is related to the long-term stability of a marriage. Therefore, while we know our sample is positively selected on marital surplus, we do not know if it is selected on a particular source of marital surplus. But our results do suggest that joint time consumption may be a source of marital surplus, warranting further analysis. 


\section{References}

Becker, Gary. 1981. A Treatise on the Family. Cambridge: Harvard University Press.

Connelly, Rachel, and Jean Kimmel. 2009. "Spousal Influences on Parents' Non-Market Time Choices." Review of the Economics of the Household 7: 361-394.

Fisher, Kimberly, Muriel Egerton, Jonathan I. Gershuny, and John P. Robinson . 2007. "Gender Convergence in the American Heritage Time Use Study.” Social Indicators Research 82: 1-33.

Hallberg, Daniel. 2003. "Synchronous Leisure, Jointness and Household Labor Supply.” Labour Economics 10: 185-203.

Hamermesh, Daniel S. 2002. “Timing, Togetherness and Time Windfalls.” Journal of Population Economics 15: 601-623.

Hamermesh, Daniel S., Harley Frazis, and Jay Stewart. 2005. "Data Watch: The American Time Use Survey.” Journal of Economic Perspectives, 19(1): 221-232.

Jenkins, Stephen, and Lars Osberg. 2005. "Nobody to play with? The Implications of Leisure Coordination.” In D. Hamermesh and G. Pfann (Eds.), The Economics of Time Use, pp. 113-145. Amsterdam: Elsevier.

Kamo, Yoshinori. 2000. "He Said, She Said”: Assessing Discrepancies in Husbands' and Wives' Reports on the Division of Household Labor.” Social Science Research 29: 259-476.

Lam, David, 1988. "Marriage Markets and Assortative Mating with Household Public Goods: Theoretical Results and Empirical Implications.” Journal of Human Resources 23(4):462-487.

Lee, Yun-Suk, and Linda J. Waite. 2005. “ Husbands' and Wive’s Time Spent on Housework: A comparison of Meaures.” Journal of Marriage and Family 67: 328-336.

Lundberg, Shelly. 2012. "Personality and Marital Surplus.” IZA Journal of Labor Economics. 1(3)

Lundberg, Shelly and Elaina Rose. 1999. "The Determinants of Specialization in Marriage,” unpublished manuscript.

Morrill, Melinda and Sabrina Pabilonia, 2012. "What Effect do Macroeconomic Conditions Have on Families’ Time Together?” IZA Discussion Paper \#6529.

Stevenson, Betsey and Justin Wolfers. 2007. "Marriage and Divorce: Changes and Their Driving Forces.” Journal of Economic Perspectives 21(2): 27-52. 
Sullivan, Oriel. 1996. "Time Co-Ordination, the Domestic Division of Labour and Affect Relations: Time-Use and the Enjoyment of Activities within Couples.” Sociology 30(1): 97-100. 


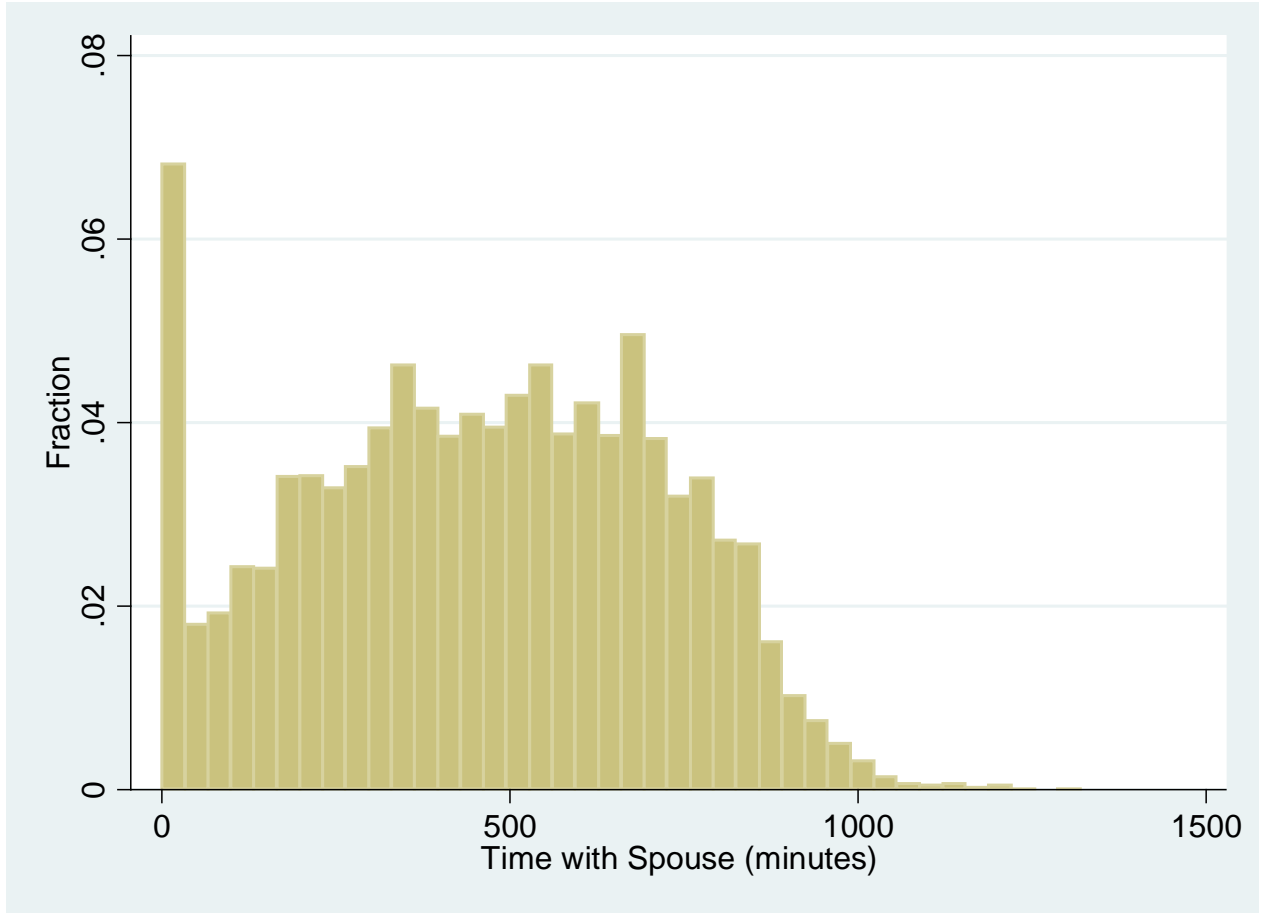

Fig 1. Distribution of time with spouse on weekend day off, full sample

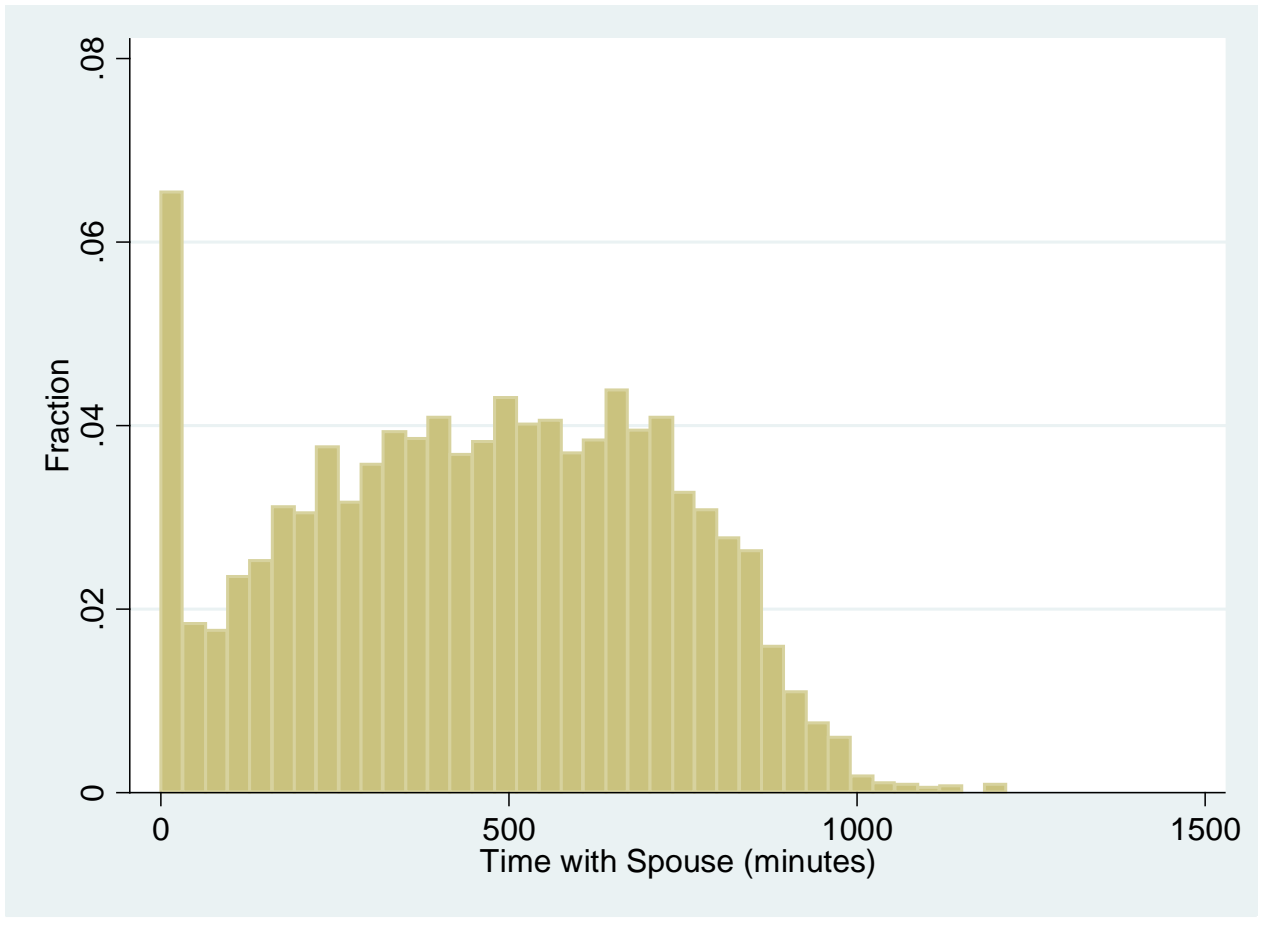

Fig 2. Distribution of time with spouse on weekend day off, dual-earner sample 


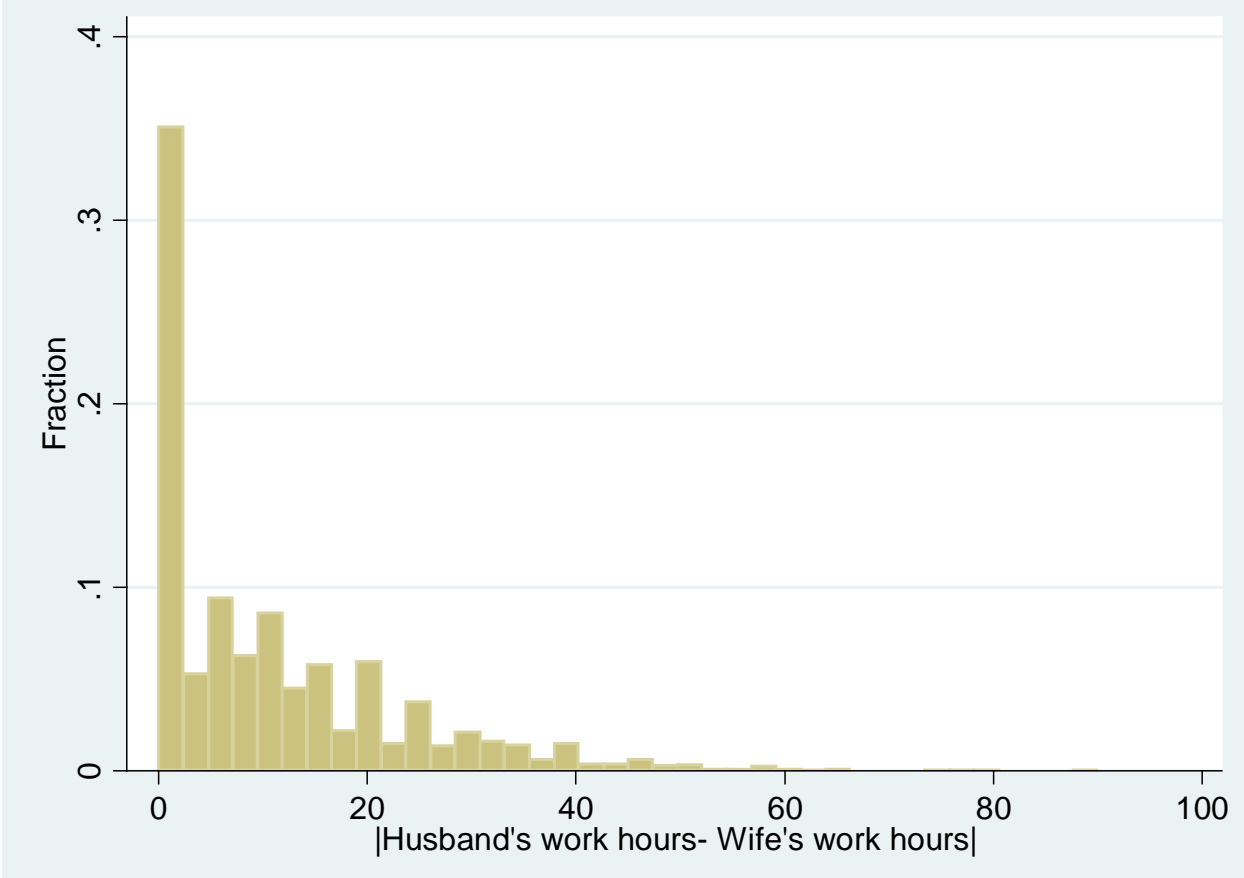

Fig 3: Distribution of absolute value of difference between husband's and wife's work hours, dual-earner sample

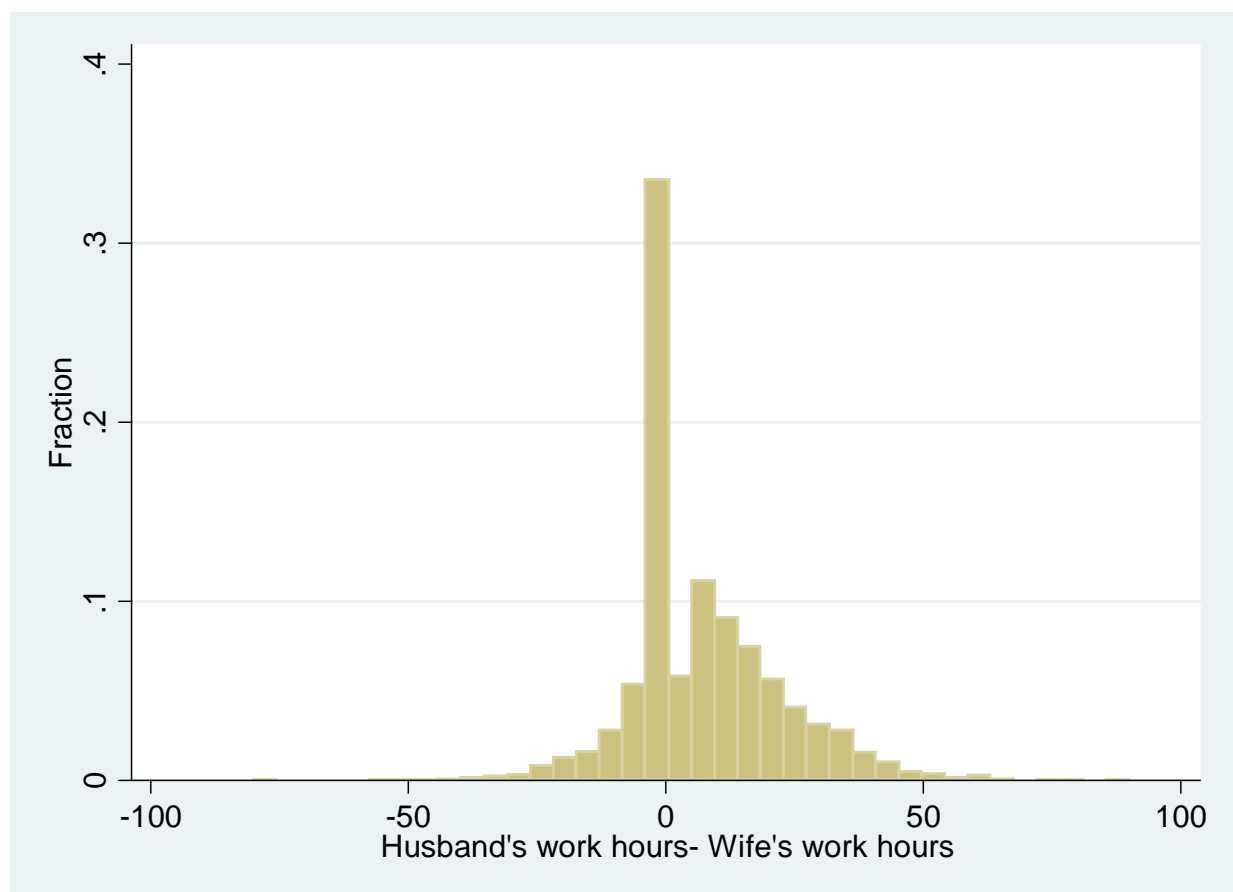

Fig 4: Distribution of Husband’s work hours minus wife’s work hours, dual-earner sample 
Table 1: Husband's and wife's characteristics

\begin{tabular}{|c|c|c|}
\hline & Full Sample & Dual-Earner Sample \\
\hline Time with Spouse (minutes) & $467.9(260.8)$ & $466.7(261.2)$ \\
\hline in household production & $137.6(154.7)$ & $137.5(155.7)$ \\
\hline in leisure & $330.3(218.7)$ & $329.2(218.1)$ \\
\hline Husband's weekly hours of work & $38.4(16.5)$ & $42.6(10.1)$ \\
\hline Wife’s weekly hours of work & $23.3(19.4)$ & $36.0(10.9)$ \\
\hline $\begin{array}{l}\text { Combined weekly earnings of } \\
\text { husband and wife }\end{array}$ & $1441.8(899.5)$ & $1719.3(894.0)$ \\
\hline Husband’s hourly earnings & & $28.6(77.9)$ \\
\hline Wife’s hourly earnings & & $22.8(47.9)$ \\
\hline Husband's Age & $40.3(8.6)$ & $40.7(8.4)$ \\
\hline Wife’s Age & $38.6(8.7)$ & $39.1(8.5)$ \\
\hline $\begin{array}{l}\text { Husband \% with high school } \\
\text { degree }\end{array}$ & $88.1 \%$ & $92.3 \%$ \\
\hline Husband \% with college degree & $34.1 \%$ & $34.8 \%$ \\
\hline Wife \% with high school degree & $89.8 \%$ & $93.8 \%$ \\
\hline Wife \% with college degree & $35.0 \%$ & $38.3 \%$ \\
\hline Husband \% non-Hispanic white & $70.0 \%$ & $74.9 \%$ \\
\hline Husband \% non-Hispanic black & $7.0 \%$ & $7.5 \%$ \\
\hline Husband \% Hispanic & $17.7 \%$ & $13.1 \%$ \\
\hline Wife \% non-Hispanic white & $69.9 \%$ & $74.8 \%$ \\
\hline Wife \% non-Hispanic black & $6.4 \%$ & $7.0 \%$ \\
\hline Wife \% Hispanic & $17.7 \%$ & $12.9 \%$ \\
\hline Number of Children & $1.33(1.16)$ & $1.17(1.10)$ \\
\hline \% with child under 6 & $34.6 \%$ & $27.5 \%$ \\
\hline $\mathrm{N}$ & 11,735 & 6,447 \\
\hline
\end{tabular}

Notes: Full sample is ATUS 2003-2011 respondents who are a) married, b) both husband and wife are ages 20-55, c) filled out the time diary on a weekend and d) did not perform any market work on their diary day. Dual-earner sample is restricted to couples in which both husband and wife report positive weekly hours of work. Sample means are weighted with ATUS personal sampling weights. 
Table 2: Time with spouse, Dual-earner sample

Total time with spouse

(1)

(2)
|Husband's hours

-Wife's hours|

Husband's hours

-Wife's hours|*Female

Husband's hours

-Wife's hours|*Male

|(Husband's wage

-Wife’s wage)|

Log (combined weekly

earnings)

Wife's hours

Wife’s Wage

Female

Husband's age

Husband's age squared

Wife's age

Wife’s age squared

Husband high school

degree

Husband college

degree

Husband advanced

degree

Wife high school

degree

Wife college degree

Wife advanced degree

1.05 (10.19)

1.07 (10.17)

$-1.27(0.431)^{* *}$

0.042 (0.083)

$-39.7(7.6) * * *$

-2.27 (6.86)

-2.18 (6.86)

$-0.000(0.083)$

0.954 (6.67)

0.864 (6.67)

$-0.050(0.084)$

-2.48 (18.20)

-2.90 (18.18)

$-11.4(20.6)$

$-12.0(20.6)$

16.3 (15.3)

-4.32 (22.8)

12.3 (12.7)

5.89 (19.5)

29.5 (14.4)

29.8 (21.5)

$34.3(23.3)$

34.7 (23.3) $-1.36(0.375) * * *$

$$
-0.078(0.049)
$$

HH Production

(3)

(4)

Leisure

$$
\begin{array}{lll}
-1.09(0.443)^{*} & -0.453(0.260)+ & -0.638(0.362)+ \\
-1.68(0.519)^{* * *} & -0.553(0.281)^{*} & -1.13(0.447)^{*} \\
-0.074(0.049) & -0.068(0.024)^{* *} & -0.006(0.045)
\end{array}
$$

2.07 (5.79)

-1.00 (8.59)

$-1.26(0.428)^{* *}$

$0.315(0.225)$

$-0.944(0.360)^{* *}$

0.035 (0.083)

0.032 (0.033)

0.003 (0.071)

$-45.8(9.9) * * *$

$4.73(6.25)$

$-50.5(8.5)^{* * *}$

5.15 (3.96)

$-7.33(5.75)$

$-0.001(0.083)$

$-0.058(0.048)$

0.057 (0.070)

$0.851(4.03)$

0.013 (5.5)

$-0.049(0.084)$

$-0.028(0.050)$

$-0.021(0.069)$

-5.76 (10.9)

-8.66 (15.5)

$3.42(12.0)$

-15.4 (17.3)

$-2.45(13.0)$

-1.87 (19.3)

$-6.90(12.8)$

12.8 (16.7)

-0.302 (13.9)

30.1 (18.2)+

$-0.005(15.0)$

34.7 (20.0)+ 


\begin{tabular}{|c|c|c|c|c|}
\hline 1 child & $-48.8(15.7)^{* *}$ & $-48.6(15.7)^{* *}$ & $-23.2(8.8)^{* *}$ & $-25.4(13.2)+$ \\
\hline 2 children & $-54.1(17.4)^{* *}$ & $-53.9(17.4)^{* *}$ & $-22.0(9.9)^{*}$ & $-31.9(14.9)^{*}$ \\
\hline 3 children & $-41.3(20.6)^{*}$ & $-40.9(20.6)^{*}$ & $-21.7(12.3)+$ & $-19.3(17.4)^{*}$ \\
\hline 4 or more children & $-76.0(28.1)^{* *}$ & $-76.0(28.1)^{* *}$ & $-47.7(14.3)^{* * *}$ & $-28.3(23.0)$ \\
\hline Youngest child <3 & $-14.3(17.8)$ & $-14.4(17.8)$ & $50.2(10.4)^{* * *}$ & $-64.6(15.0)^{* * *}$ \\
\hline Youngest child 3-5 & $-24.8(18.0)$ & $-25.0(18.0)$ & $27.7(10.3)^{* * *}$ & $-52.7(15.0)^{* * *}$ \\
\hline Youngest child 6-8 & $-39.0(17.6)^{*}$ & $-39.0(17.6)^{*}$ & 7.21 (9.93) & $-46.3(14.9)^{* *}$ \\
\hline Youngest child 9-11 & $-9.55(17.8)$ & $-9.94(17.6)$ & $1.15(9.65)$ & $-11.1(15.1)$ \\
\hline Youngest child 12-14 & 4.15 (17.4) & $4.02(17.4)$ & $11.8(9.8)$ & $-7.8(14.6)$ \\
\hline Sunday & $-3.24(7.57)$ & $-3.26(7.56)$ & $8.76(4.56)$ & $-12.0(6.4)+$ \\
\hline $\begin{array}{l}\text { Controls for husband's } \\
\text { and wife's } \\
\text { race/ethnicity }\end{array}$ & $\mathrm{Y}$ & $\mathrm{Y}$ & $\mathrm{Y}$ & $\mathrm{Y}$ \\
\hline Year fixed-effects & $\mathrm{Y}$ & $\mathrm{Y}$ & $\mathrm{Y}$ & $\mathrm{Y}$ \\
\hline $\mathrm{N}$ & 6,447 & 6,447 & 6,447 & 6,447 \\
\hline
\end{tabular}

Notes: Sample is dual-earner sample described in notes of Table 1. Table reports estimates from equation (1). All regressions are weighted with ATUS personal sampling weights. Robust standard errors in parentheses. + p-value $<0.10 *$ p-value $<0.05 * *$ p-value $<0.01 * * *$ pvalue $<0.001$ 
Table 3: Symmetry by primary worker, Dual-earner sample

Total Time with Time with Time with Spouse Spouse

(1) (2)

\section{|Husband's hours-Wife's} hours|*1(Husband's hours greater)

|Husband's hours-Wife's hours $\left.\right|^{*} 1$ (Wife's hours greater)

|(Husband's wage

-Wife's wage)|

Log (combined weekly earnings)

Wife's hours

Wife's wage

Wife's wage

$\mathrm{N}$

$\begin{array}{ccc}-1.22 * * & -0.499 * & -0.726 * \\ (0.439) & (0.246) & (0.361)\end{array}$

$-1.75^{*}$

(0.799)

$-0.499$

(0.419)

$-1.25+$

(0.669)

$-0.065$

$-0.069 *$

0.004

(0.027)

(0.048)

2.06

(5.95)

$-2.06$

(10.3)

(8.61)

$-0.317$

$-0.757+$

(0.300)

(0.440)

$(0.530)$

0.033

(0.033)

0.004

$(0.072)$

(0.084)
6,447

6,447

Notes: Sample is dual-earner sample described in notes of Table 1. Table reports estimates from equation (2). Regressions include all control variables included in Table 2, and are weighted using ATUS personal sampling weights. Robust standard errors in parentheses. + p-value $<0.10$ * p-value $<0.05 * *$ p-value $<0.01{ }^{* * *}$ p-value $<0.001$ 
Table 4: Time with Spouse by Age of Youngest child, Dual-Earner Sample

$\begin{array}{llll}\begin{array}{l}\text { Youngest } \\ \text { Child }<13\end{array} & \begin{array}{l}\text { Youngest } \\ \text { Child 13-17 }\end{array} & \begin{array}{l}\text { No Children } \\ \text { under 18 \& } \\ \text { Wife's Age } \leq 36\end{array} & \begin{array}{l}\text { No Children } \\ \text { Under 18 \& }\end{array} \\ \text { Wife's Age } \geq 37 \\ \text { (1) } & \text { (2) } & (3) & \text { (4) }\end{array}$

\begin{tabular}{|c|c|c|c|c|}
\hline $\begin{array}{l}\text { |Husband's hours- } \\
\text { Wife's hours| }\end{array}$ & $\begin{array}{l}0.248 \\
(0.468)\end{array}$ & $\begin{array}{l}-1.78 * \\
(0.730)\end{array}$ & $\begin{array}{l}-4.82 * * * \\
(1.46)\end{array}$ & $\begin{array}{l}-2.53 * * \\
(0.927)\end{array}$ \\
\hline $\begin{array}{l}\mid \text { (Husband's wage } \\
\text {-Wife's wage)|}\end{array}$ & $\begin{array}{l}-0.214^{*} \\
(0.102)\end{array}$ & $\begin{array}{l}-0.014 \\
(0.061)\end{array}$ & $\begin{array}{l}-0.379 * * * \\
(0.085)\end{array}$ & $\begin{array}{l}0.024 \\
(0.062)\end{array}$ \\
\hline $\begin{array}{l}\text { Log (combined } \\
\text { weekly earnings) }\end{array}$ & $\begin{array}{l}-6.12 \\
(11.7)\end{array}$ & $\begin{array}{l}-2.32 \\
(22.6)\end{array}$ & $\begin{array}{l}34.5 \\
(50.2)\end{array}$ & $\begin{array}{l}5.39 \\
(25.0)\end{array}$ \\
\hline Wife's hours & $\begin{array}{l}-0.198 \\
(0.529)\end{array}$ & $\begin{array}{l}-0.959 \\
(0.858)\end{array}$ & $\begin{array}{l}-4.41^{*} \\
(1.82)\end{array}$ & $\begin{array}{l}-0.965 \\
(1.04)\end{array}$ \\
\hline Wife's wage & $\begin{array}{l}0.193 \\
(0.128)\end{array}$ & $\begin{array}{l}-0.104 \\
(0.084)\end{array}$ & $\begin{array}{l}-0.779 \\
(1.81)\end{array}$ & $\begin{array}{c}0.172 \\
(0.308)\end{array}$ \\
\hline $\mathrm{N}$ & 4,122 & 887 & 454 & 984 \\
\hline
\end{tabular}

Notes: Sample is dual-earner sample described in notes of Table 1. Table reports estimates from equation (1) separately by presence of young children. Regressions include all control variables included in Table 2 and are weighted with ATUS personal sampling weights. Robust standard errors in parentheses. + p-value $<0.10 *$ p-value $<0.05 * *$ p-value $<0.01 * * *$ p-value $<0.001$ 
Table 5: Time with Spouse, Full Sample

$\begin{array}{lll}\text { Time with Spouse } & \text { Time w/Spouse } & \text { Time w/ Spouse } \\ \text { in HH Prod } & \text { in Leisure }\end{array}$

(1)

(2)

(3)

\begin{tabular}{llll}
\hline Husband's hours-Wife's & $-0.606^{*}$ & $-0.252+$ & $-0.354+$ \\
hours|*1(Husband's hours greater) & $(0.252)$ & $(0.136)$ & $(0.209)$ \\
|Husband's hours-Wife's & $-0.691^{*}$ & -0.228 & $-0.463+$ \\
hours|*1(Wife's hours greater) & $(0.319)$ & $(0.181)$ & $(0.265)$ \\
& & & \\
Log (combined weekly earnings) & 3.83 & $7.16^{*}$ & -3.32 \\
& $(5.80)$ & $(3.30)$ & $(5.03)$ \\
Wife's hours & -0.557 & -0.051 & -0.506 \\
& $(0.381)$ & $(0.207)$ & $(0.321)$ \\
Wife's hours=0 & 9.67 & 5.79 & 3.88 \\
& $(12.54)$ & $(7.15)$ & $(10.69)$ \\
$\mathrm{N}$ & & & \\
\hline
\end{tabular}

Notes: Sample is full sample described in Notes of Table 1. Regressions include all control variables included in Table 2 (other than those for wife's wage) and are weighted with ATUS personal sampling weights. Robust standard errors in parentheses. + p-value $<0.10 *$ pvalue $<0.05 * *$ p-value $<0.01 * * *$ p-value $<0.001$ 
Table 6: Time with Spouse by Age of Youngest child, Full Sample

\begin{tabular}{llll}
$\begin{array}{l}\text { Youngest } \\
\text { Child }<13\end{array}$ & $\begin{array}{l}\text { Youngest } \\
\text { Child 13-17 }\end{array}$ & $\begin{array}{l}\text { No Children } \\
\text { under 18 \& } \\
\text { Wife’s Age } \leq 36\end{array}$ & $\begin{array}{l}\text { No Children } \\
\text { Under 18 \& } \\
\text { Wife's Age } \geq 37 \\
(1)\end{array}$ \\
(2) & $(3)$ & $(4)$ \\
\hline
\end{tabular}

\begin{tabular}{lllll} 
|Husband's hours- & -0.308 & -0.406 & $-2.14^{* *}$ & $-1.44^{* *}$ \\
Wife's hours $\mid$ & $(0.236)$ & $(0.550)$ & $(0.813)$ & $(0.502)$ \\
& & & & \\
Log (combined & $12.0+$ & -15.86 & 9.27 & -7.60 \\
weekly earnings) & $(6.3)$ & $(13.85)$ & $(22.79)$ & $(14.84)$ \\
Wife's hours & -0.467 & 0.079 & $-2.81+$ & -0.091 \\
& $(0.377)$ & $(0.876)$ & $(1.51)$ & $(0.878)$ \\
Wife's hours=0 & -3.42 & 9.90 & -45.1 & $78.22^{*}$ \\
& $(13.70)$ & $(32.44)$ & $(61.6)$ & $(35.6)$ \\
$\mathrm{N}$ & & & & \\
\hline
\end{tabular}

Notes: Sample is full sample described in notes of Table 1. Table reports estimates from equation (1) separately by presence of young children. Regressions include all control variables included in Table 2 (other than those for wife's wage) and are weighted with ATUS personal sampling weights. Robust standard errors in parentheses. + p-value $<0.10 *$ p-value $<0.05{ }^{* *}$ pvalue $<0.01 * * *$ p-value $<0.001$ 